Katarzyna Wrońska*

Kraków

\title{
Liberal education w Polsce. Między kształceniem ogólnym a edukacją liberalną
}

\section{Wprowadzenie}

Wybór tematu nie jest przypadkowy. Wynika on z konstatacji o słabej jego obecności w obszarze polskiej humanistyki, a wręcz nikłej w naukach pedagogicznych i praktyce edukacyjnej. Przeciwnie do sytuacji w obszarze anglosaskim, gdzie nasycenie tematem jest duże, o czym świadczą liczne publikacje filozofów i pedagogów poświęcane stale liberal education ${ }^{1}$. Wprost

* Dr hab. Katarzyna Wrońska jest adiunktem w Zakładzie Pedagogiki Ogólnej i Filozoficznej w Instytucie Pedagogiki Uniwersytetu Jagiellońskiego.

${ }^{1}$ W ujęciu chronologicznym zob. m.in.: J. Priestley, Lectures on History and General Policy to which is prefixed An Essay on the Course of liberal Education for civil and active Life [1788], London 1826; J. Snelling Popkin, Three Lectures on Liberal Education, Cambridge 1836; J. H. Newman, The Idea of a University, London 1899; Ch. Bailey, Beyond the Present and the Particular: A Theory of Liberal Education, London 1984; B. A. Kimball, Orators \& Philosophers. A History of the Idea of Liberal Education, New York and London 1986; A. Bloom, The Closing of the American Mind, New York 1987; M. Useem, Liberal Education and the Corporation; The Hiring and Advancement of College Graduates, New York 1989; B. A. Kimball, Toward Pragmatic Liberal Education, w: B. A. Kimball, R. Orrill (red.), The Condition of American Liberal Education. Pragmatism and a Changing Tradition, New York 1995, s. 1-122; M. C. Nussbaum, Cultivating Humanity: A Classical Defense of Reform in Liberal Education, Cambridge 1997; M. Levinson, The Demands of Liberal Education, Oxford 1999; B. Smith (red.), Liberal education in a Knowledge Society, Chicago and La Salle, Illinois 2002; D. Conway, Liberal Education and the National Curriculum, London 2010; V. Ferrall, Jr., 
termin ten zaczął być przywoływany w rozważaniach tamtejszych filozofów poczynając od epoki oświecenia. Jedno z pierwszych dzieł w całości dedykowane temu zagadnieniu wyszło spod pióra George'a Turnbulla, szkockiego teologa i filozofa, w roku $1742^{2}$. Retrospektywnie próbuje się odnajdywać wątki liberal education już np. w myśli Johna Locke'a, choć w jego tekstach termin ten jeszcze nie występuje. Nie ma go też w głównym dziele Adama Smitha The Wealth of Nations z 1776, choć interesująca nas tu kwestia została w nim podjęta. Studiowanie bogatej literatury na ten temat utwierdza w przekonaniu, że jest on wart eksploracji sam dla siebie.

Zakłada się, że w polskiej pedagogice mocniejsze ugruntowanie ma teoria kształcenia ogólnego, nawiązująca głównie do oświeceniowej i neohumanistycznej koncepcji Bildung, zaś wpływ anglosaskiej myśli i rozwijanej w jej obrębie edukacji liberalnej jest znacząco słabszy. Tezę o słabej recepcji anglosaskiego nurtu edukacyjnego w Polsce wzmocniłabym jeszcze następną, wedle której polską kulturę znamionuje także słabe zakorzenienie tradycji liberalizmu. Nie sposób bowiem nie dostrzec wkładu, jaki do koncepcji liberal education wnosili i wciąż wnoszą liberałowie, w tym jej anglosascy przedstawiciele ${ }^{3}$. W mojej ocenie dopiero oba czynniki razem wzięte, a więc opór i dystans w stosunku do zamysłów edukacyjnych o anglosaskiej proweniencji dodatkowo kojarzonych z liberalizmem, wyjaśniają przyczyny słabej obecności i ugruntowania „edukacji liberalnej” w Polsce.

W tym miejscu można przywołać kilka przykładów z obszaru translatoryki. W niektórych tekstach angielskich zwrot liberal education w polskim tłumaczeniu przykrojony zostaje do oswojonej dla polskiego czytelnika formy „kształcenia ogólnego", w innych zaś, o ile tłumacz ryzykuje inne określenie, na przykład „wolne wykształcenie”, „swobodne wykształcenie”, „edukacja liberalna”, często uznaje za zasadne wyjaśnić, dlaczego zastosował taki zwrot, z odwołaniem do angielskiej tradycji umysłowej i jej przy-

Liberal Arts at the Brink, Cambridge 2011; J. M. Shephard, S. M. Kosslyn, E. M. Hammonds (red.), The Harvard Sampler. Liberal Education for the Twenty-First Century, Cambridge 2011; D. R. DeNicola, Learning to Flourish. A Philosophical Exploration of Liberal Education, New York, London 2012.

${ }^{2}$ G. Turnbull, Observations upon Liberal Education [1742], red. by T. O. Moore, Jr., Indianapolis 2003.

3 Zob. zwłaszcza zasługi na tym polu Johna Stuarta Milla, Davida Conwaya czy Marthy Nussbaum.

${ }^{4}$ Zob. np. praca M. Nussbaum, Cultivating Humanity. A Classical Defense of Reform in Liberal Education, Cambridge 1997 w thumaczeniu polskim jako $W$ trosce o człowieczeństwo. Klasyczna obrona reformy kształcenia ogólnego, przeł. A. Męczkowska, Wrocław 2008. 
wiązania na przykład do idei swobód jednostki, względnie argumentować, że użyty zwrot „liberalny” nie musi być kojarzony z liberalizmem. Zobaczmy to na przykładzie amerykańskiej debaty wokół kryzysu kształcenia uniwersyteckiego.

Dwa ważne stanowiska w tej sprawie, oba wypowiadające się na rzecz potrzeby utrzymywania $\mathrm{w}$ szkolnictwie wyższym humanistycznego programu liberal education, sformułowali kolejno: Allan Bloom w pracy The Closing of the American Mind, oraz Martha Nussbaum, autorka Cultivating Humanity. A Classical Defense of Reform in Liberal Education. Oba nośne teksty znane są polskiemu czytelnikowi za sprawą przekładów. O ile jednak pierwsze stanowisko możemy percypować jako rozważania wokół „edukacji liberalnej”, bo taką wykładnię zdecydował się zastosować thumacz tomu Tomasz Bieroń (o czym więcej za chwilę), o tyle rozważania Nussbaum, choć będące polemiczną odpowiedzią Bloomowi, przeniesione zostają - w wyniku zastosowania przez tłumacza Astrid Męczkowską innej wykładni rozumienia terminu - w obszar dyskusji na temat kształcenia ogólnego. W mojej ocenie sytuację tę można tłumaczyć po prostu słabym zadomowieniem w naszym obszarze kulturowym anglosaskiego nurtu edukacyjnego w całości. Wyraźnie wyodrębniająca się w jego obrębie koncepcja liberal education nie stanowi monolitu. W swym historycznym przebiegu ulega ona wciąż przemianom i zróżnicowaniu, podtrzymując jednak w niezmienionym kształcie kilka wieków temu ukutą dobrze ugruntowaną nazwę. Stąd pod jednym szyldem liberal education mogą stać naprzeciw siebie choćby wspomniane wyżej racje Blooma broniące kanonu wielkich klasycznych ksiagg, jak i argumenty Nussbaum na rzecz wielokulturowości, obywatelstwa i kultywowania wyobraźni literackiej wśród studentów. Problem ten w pewien sposób sygnalizuje Tomasz Bieroń w przypisie tłumaczącym użycie sformułowania angielskiego, czyli „edukacji liberalnej”, zamiast polskiego odpowiednika, czyli, jak pisze, „kształcenia ogólnego” czy „edukacji kulturalnej”. O ile wyróżniki „liberalnej” edukacji, jak wyjaśnia, oznaczają głównie „nieskrępowanie wymogami użyteczności czy praktyczności i podległość jedynie zasadom rozumu”, o tyle wyróżniki „ogólnego” kształcenia bądź „kulturalnej” edukacji „wskazują raczej na takie cechy, jak ogłada czy erudycja"5. Z tych samych powodów dalej będę stosować oryginalną angielską pisownię lub jej polskie tłumaczenie - „edukacja liberalna” - najbliższe wersji angielskiej.

${ }^{5}$ Zob. przypis thumacza w „Przedmowie” A. Blooma w tegoż: Umyst zamknięty: o tym, jak amerykańskie szkolnictwo wyższe zawiodto demokrację i zubożyło dusze dzisiejszych studentów, Poznań 2012, s. 21. 
W niniejszym opracowaniu koncepcję liberal education proponuje się poddać analizie pod kątem jej recepcji w polskiej współczesnej myśli pedagogicznej i szerzej w polskiej humanistyce ${ }^{6}$. W pierwszym rzędzie trzeba będzie określić wyróżniki liberal education $\mathrm{z}$ intencją możliwości odnajdywania ich w dzisiejszych realiach edukacji na różnych jej szczeblach, w tym w obrębie obowiązkowej nauki szkolnej. W następnej kolejności niezbędne okaże się przywołanie podobnych, równolegle rozwijanych koncepcji, w tym głównie koncepcji kształcenia ogólnego, mającej u nas mocniejsze ugruntowanie. Analiza porównawcza obu koncepcji posłuży zebraniu niezbędnych danych, by móc odpowiedzieć na kilka kluczowych pytań wywołanych podjętym tematem. Mianowicie, co wyróżnia koncepcję edukacji liberalnej w stosunku do koncepcji kształcenia ogólnego? Co zyskujemy a co tracimy sięgając wyraźniej do jednej z tradycji, zaniedbując osiągnięcia i wyróżniki drugiej? Czy są szanse na większą równowagę w budowaniu naszego rodzimego systemu edukacji publicznej formalnej i nieformalnej, czyli na czerpanie z mocnych stron obu koncepcji? Na końcu, zakładam, że uda się także sformułować postulaty odniesione do teorii pedagogicznej i praktyki edukacyjnej z ambicją ożywienia i wyodrębnienia w nich miejsca dla edukacji liberalnej.

\section{Wyróżniki liberal education}

By móc wskazać wyróżniki liberal education, trzeba się cofnąć do początków kształtowania się tej koncepcji, a te umieszcza się już w epoce starożytnej. Łączy się je z filozofią Arystotelesa i jego koncepcją wiedzy godnej człowieka wolnego, a więc jako dobra w zasięgu możliwości i starań człowieka wolnego od konieczności zabiegania o środki utrzymania, sięgającego po wiedzę $\mathrm{w}$ czasie wolnym, a nie w związku z pracą zawodową. Rozwiniętą postać otrzymuje w wiekach średnich w modelu siedmiu sztuk wyzwolonych (artes liberales), przygotowujących do podjęcia studiów uniwersyteckich. Wyraźną cezurą w jej dziejach wydaje się wiek XVIII, z jego

${ }^{6}$ Omówienie przebiegu recepcji, poczynając od oświecenia, jest badaniem wykraczającym poza ramy tego opracowania; to zadanie już w części zostało zrealizowane w innej publikacji, tj. Liberal Education in Selected Polish Pedagogical Concepts - in Comparison to English-language Concepts - with Particular Reference to the Enlightenment, „Kultura i Wychowanie" 5 (2013), s. 33-38 (cz. 1) oraz nr 6 (2013), s. 9-21 (cz. 2), zaś szersze studia nad dziejami liberal education w Polsce zaplanowane są jako odrębny projekt cyklu opracowań, w tym pracy zbiorowej i monografii. 
filozofią oświecenia i liberalizmem, które nie pozwoliły jej na zastygnięcie w scholastycznej formule i niezwiązanie z idea postępu. Od tego też czasu możemy sięgać po teksty, w których znajdujemy wykład interesującej nas tu koncepcji nazywanej wprost liberal education. Dzisiaj formułowane jej wyróżniki daje się odszyfrowywać poprzez pamięć dla jej wcześniejszych postaci, ale nie ogranicza to dyskusji na temat tego, jak ją rozumieją współcześni, a więc co dziś znaczy i co powinna wnosić jej liberalność.

W obszarze myśli brytyjskiej punktem zwrotnym w rozumieniu tego pojęcia było stanowisko zaprezentowane na początku lat 70. XX wieku przez Richarda S. Petersa, który zapoczątkował dyskusję w gronie pedagogów i filozofów, prezentowaną między innymi na łamach „Journal of Philosophy of Education"; w jej wyniku pojawiło się kilka bardzo ciekawych ujęć liberal education ${ }^{7}$. Ta wymiana trwa do dziś, wskazując na żywotność pojęcia i jego rozszerzający się zakres stosowania, obejmujący duży obszar edukacji poprzedzający jej sprofilowanie związane $\mathrm{z}$ wyborem ścieżki kształcenia zawodowego i specjalistycznych studiów (ewentualnie prowadzony równolegle z nimi) ${ }^{8}$. W obszarze myśli amerykańskiej dyskusja jest równie dynamiczna, jednak pojęciem tym obejmuje się przede wszystkim kształcenie w ramach kolegiów lub kursów „Artes Liberales” (College of Liberal Arts lub College of Liberal Arts \& Sciences), organizowanych w szkołach wyższych i w uniwersytetach, poprzedzających lub uzupełniających specjalistyczną edukację wyższą. Wspomniana wyżej wymiana między Bloomem i Nussbaum dotyczy sporów na temat sensu i sposobu prowadzenia właśnie takich studiów i kursów9

W poniższym opracowaniu przyjmuje się szerszą wykładnię rozumienia liberal education, jako tę, odnoszącą się do edukacji w ogóle, w tym także a nie wyłącznie do jej akademickiej postaci. Ale nie mieszczą się w niej

7 Zob. szerzej: Ch. Winch, J. Gingell, Philosophy of Education, London 2008, s. 120-124.

${ }^{8}$ Kwestią sporną pozostaje punkt startowy edukacji liberalnej. W jakim stopniu jest ona możliwa na poziomie edukacji podstawowej? Rzecz wymaga głębszej analizy i badań. Osobiście skłaniam się bronić tezy o jej dostępności od najwcześniejszych lat (za dobry przykład służą akademie dziecięce cieszące się bardzo dużym zainteresowaniem samych dzieci i ich rodziców).

${ }^{9}$ W tym miejscu warto zaznaczyć wkład do rozwoju tej instytucji również Polski, a konkretnie Uniwersytetu Warszawskiego, gdzie działa Wydział Artes Liberales, choć jest to na razie tylko 1 taka instytucja w naszym kraju. Na Uniwersytecie Jagiellońskim uruchamiany jest, obok Międzyuczelnianych Interdyscyplinarnych Studiów Humanistycznych (podobnie jak na UW), cykl wykładów otwartych Artes Liberales przeznaczony dla studentów i doktorantów, którzy uczestniczą w nich dobrowolnie, a zaliczony testem kurs pozwala uzyskać 3 punkty ECTS. 
praktyki zorientowane utylitarnie, ideologicznie i ściśle praktycznie, służące przygotowaniu do wykonywania konkretnego zawodu, wpojeniu doktryny bądź opanowaniu konkretnych umiejętności. Stąd nie jest nią praktyka instruktażu, szkolenia, jednostronnego przekazu gotowej wiedzy i indoktrynacji ani edukacja początkowa, przynajmniej w takim stopniu, w jakim skupia się ona na uczeniu podstawowych umiejętności (w tym pisania, czytania, liczenia), służących wraz z podstawami wiedzy jako baza dla dalszego procesu kształcenia się. Idąc za wykładnią Richarda S. Petersa, edukacja liberalna wyróżnia się dbałością o trzy aspekty uczenia się, mianowicie: o wartościowe (cenne dla siebie) treści nauczania, szeroką perspektywę poznawczą opartą na rozumieniu oraz o niedogmatyczny i nienarzucający przekaz treści z odwołaniem do dobrowolności i gotowości przyjęcia go przez uczniów ${ }^{10}$.

Pierwszy wyróżnik wiąże się z potrzebą rozwijania w młodych ludziach chęci uczenia się nie dla korzyści, zawodu, prestiżu, ale jako aktywności angażującej uwagę ze względu na wewnętrzną wartość poznawanych treści. Nietrudno dostrzec tu ślad myśli Arystotelesa i średniowiecznej formuły sztuk wyzwolonych jako pierwowzoru dla tego wyróżnika. Edukacja liberalna przeciwstawiana jest bardzo mocno kształceniu zawodowemu ze względu na jej treści niepoddające się kryterium użyteczności. Składa się na nią wiedza służąca kształceniu przez nią wolnej, dojrzałej, świadomej siebie i odpowiedzialnej osoby w kontakcie z treściami kultury. John Stuart Mill, mając możliwość wygłoszenia pochwały edukacji liberalnej podczas swej mowy rektorskiej, uciekł się do apelu o otwarte umysły: „nie dajcie przehandlować swojej wolności myśli" "11, skierowanego i do wykładowców, i do studentów.

Drugi wyróżnik akcentujący szeroką perspektywę poznawczą wskazuje na potrzebę uwzględniania w procesie uczenia się obok ściśle naukowego, na przykład przyrodoznawczego, oglądu danych treści również prezentowania poznawanej rzeczywistości na przykład w jej historycznej perspektywie, z uwzględnieniem społecznego sensu czy estetycznego wymiaru oraz innych możliwych interpretacji i rozumienia poznawanych treści. Tu z kolei wyraźnie daje o sobie znać późnooświeceniowy i neoklasyczny postulat wszechstronności czyli ogólności edukacji, stąd jej możliwe odmiany czy interpretacje jako „edukacji ogólnej” bądź „kształcenia ogólnego” z udziałem w jej formułowaniu Wilhelma von Humboldta, ale także J. S. Milla.

10 Zob. R. S. Peters, Ethics and Education, London 1970, s. 43-45.

11 J. S. Mill, Inaugural Address at St. Andrews, w: F. A. Cavenagh (red.), James \& John Stuart Mill on Education, Cambridge 1931, s. 187. 
Trzeci wyróżnik edukacji liberalnej to jej dbałość o uwzględnianie w nauczaniu podmiotowości i aktywności uczącego się, tak by umiał zachować przekonanie o swobodnym, dobrowolnym i krytycznym udziale w poznaniu i interpretowaniu poznawanych treści. Ów trzeci wyróżnik wydaje się najmocniej wiązać tę koncepcję z dziedzictwem oświecenia, w tym z kształtującym się w jego obrębie liberalizmem. W myśl zasad oświecenia rozum jest jedyną instancją, przed którą człowiek winien jest ustapić, nie sposób bowiem nie uznać jego racji, które są niepodważalne ${ }^{12}$. Edukacja kształcąca rozum miała stać się kluczem do wyzwolenia człowieka z pęt wszelkiej niewoli, w tym z zależności od własnych przesądów, namiętności, ale i poddania woli innych, łącznie z władzą autorytetu, będącej wynikiem niewiedzy i niesamodzielności w myśleniu i rozumowaniu. Wkład klasycznego liberalizmu do rozwoju badanej tu koncepcji edukacji jest bezsprzeczny właśnie przez podkreślanie faktu, że wiedza ma faktycznie moc zmiany kondycji człowieka. Jest sposobem na uzyskanie niezależności, uformowanie mocnego charakteru, ogładę, życie zgodne z własnym wyborem, z wykształconym poczuciem odpowiedzialności za swój los. Nie sposób nie wyróżnić w tym miejscu Johna Locke'a i jego wkładu do zmiany myślenia o nauce, który - jak pamiętamy - chciał ją realizować jako wolne od przymusu osobiste spotkanie z wiedzą, opierające się na naturalnej ciekawości świata ${ }^{13}$. O ile jednak idee oświeceniowe głównie wiążemy z przekuwaniem tej postępowej siły tkwiącej w edukacji w politykę rządzących, tworzących programy skierowane na oświecanie ludu, przygotowujące do pracy zawodowej obok odrębnej ścieżki kształcenia „liberalnego” dla elit, o tyle idee klasycznego liberalizmu kojarzymy z przerzucaniem sprawy kształcenia i wychowania z państwa na społeczeństwo obywatelskie, w imię zasady, że wiedza jest dobrem wymagającym własnego - osobistego - nim zainteresowania, a więc zarazem gotowości do ponoszenia kosztów korzystania z niej, inwestowania w nią. Liberalizm nowoczesny wyraźniej podkreśla rolę państwa wyrównującego nierówności w dostępie do edukacji, gwarantującego równy dostęp do publicznego szkolnictwa różnych szczebli.

Podsumowując, wszędzie tam, gdzie edukacja przebiega jako społeczna praktyka uczenia się, odróżnialna od innych rodzajów praktyk za sprawą jej wewnętrznych dóbr, mających zdolność doskonalenia jej uczestników, to jest uczniów i nauczycieli jako osoby, podmioty świadome, wrażliwe, ro-

12 Zob. J. Locke, O właściwym używaniu rozumu, w: tenże, Rozważania dotyczace rozumu ludzkiego, Warszawa 1955, s. 499.

${ }_{13}$ Zob. tenże, Myśli o wychowaniu, Warszawa 2002, s. 150-212. 
zumne i wolne, zdobywa ona miano edukacji liberalnej. Tymi wyzwalającymi i definiującymi ową praktykę dobrami wewnętrznymi są głównie: - napęd do poznawania rzeczywistości, rozumienia i przeżywania dóbr kultury i cywilizacji, - wola doskonalenia siebie przez wysiłek i zdyscyplinowanie właściwe dla pracy badawczej, dociekań i studiów nad przedmiotem wiedzy, w tym lekturę i ogląd źródeł, - dobrowolne zaangażowanie w twórcze działanie wespół z innymi oraz - komunikacja, wymiana myśli, poglądów, argumentowanie, dowodzenie, przekonywanie, zadawanie pytań. Edukacja na miarę wolnego człowieka zakłada szerokie, pogłębione, otwarte i swobodne pole kontaktu podmiotu uczącego się z wiedzą. Powinno więc być dla niej miejsce w szkołach i uniwersytetach. Czy faktycznie jest?

\section{Edukacja liberalna jako edukacja z pierwszej ręki}

Dobrym testem sprawdzającym liberalność edukacji, pojętą w myśl przedstawionych wyżej jej wyróżników, wydaje się nasze dzisiejsze podejście do tekstów źródłowych oraz oryginalnych dzieł i ich miejsca w procesie kształcenia. O ile umiemy bronić i argumentować za obecnością wiedzy i dóbr kultury z pierwszej ręki, tej autorskiej danej w całości czyjegoś dzieła, a nie w postaci podręcznikowego jego opracowania czy skrótu, to zarazem bronimy samej istoty edukacji liberalnej. Omówione przez kogoś zagadnienie, skrót czyjejś myśli to zadanie do zapamiętania, odpytania i zaliczenia, natomiast czyjeś autorskie dzieło czytane, oglądane, słuchane to otwarcie dialogu z autorem, którego dzieło daje do myślenia, zaprasza do interpretacji, rozumienia, z którym można się spierać, zgadzać, krytykować, a więc zadanie innego rzędu, umożliwiające prowadzenie $\mathrm{z}$ innymi wokół niego dyskusji, wymiany myśli. Nie sposób do takiej edukacji kogoś zmusić, a nawet jeśli tak się dzieje, to efekt jest mizerny. Z pewnością autor też wolałby spotykać się z chcącymi z nim rozmawiać, zaciekawionymi, wątpiącymi, spierającymi się z nim, aktywnymi uczestnikami społecznej praktyki uczenia $\operatorname{sie}^{14}$. Na ile ta perspektywa - kontaktu z oryginalnym dziełem - jest dziś w praktyce formalnego kształcenia obecna?

W ujęciu Victora Ferralla osobę wykształconą liberalnie cechuje: ciekawość, pragnienie wiedzy, rozumienia, pytajność, wątpienie, chęć badania,

${ }^{14}$ Zob. M. Oakeshott, The Idea of a University, w: tenże, The Voice of Liberal Learning, Indianapolis 2001, s. 109. 
kreatywność ${ }^{15}$. Praca nad oryginalnym tekstem stwarza kapitalne warunki dla wykształcania się tych cech; ta jednak nie znosi przymusu. Zapraszanie do spotkania z dziełem wymaga rozbudzania w uczniach ciekawości i woli uczenia się, współgra z klimatem dobrowolności. Na poziomie obowiązkowej edukacji w samej instytucji szkoły nie jest to zadanie łatwe do realizacji, wymaga tworzenia nisz sprawczości, wolnego wyboru i dobrowolności. Częściej wychodzi się z tym ambitnym celem poza szkołę i kreuje się go w przestrzeni edukacji nieformalnej (muzeum, filharmonii, teatrze, instytucie badawczym, samorządzie lokalnym itp.). Druga sytuacja jest oczywiście łatwiejsza, choć również sama szkoła na swoim terenie powinna udostępniać przestrzeń do wypełnienia przez swobodny kontakt uczniów z dziełem, ale i szerzej przez ich własną twórczą aktywność i działanie, którego efektem jest dzieło. Proponuję, by edukację z pierwszej ręki ostatecznie rozumieć właśnie w ten podwójny poszerzony sposób, zwłaszcza przez wzgląd na potrzebę rozwijania edukacji liberalnej na wcześniejszych poziomach kształcenia.

W edukacji wyższej pole do działań jest znacznie bogatsze, wskazuje też na bardziej zaawansowany charakter i nowe przejawy liberalności kształcących się młodych ludzi. Uwagi Ferralla odnoszą się wprost do edukacji na tym poziomie, a ściśle do amerykańskiego modelu kolegiów Liberal Arts. Swój wywód na temat cech osoby wykształconej liberalnie autor uzupełnia, wskazując na rozwinięte w niej następujące zdolności i umiejętności: krytycznej oceny samego siebie, sprawnego prowadzenia dyskusji oraz wypowiedzi i korespondencji pisemnej, zrozumienia i wczucia się w sytuację i kondycję drugiej osoby, korzystania w badaniach z zaawansowanych nowych technologii, uogólniania wyników i szukania dlań wspólnego mianownika, rozumienia kondycji ludzkiej, w tym przewidywania działań innych ludzi, doceniania twórczości i piękna, rozumienia dziejów i konsekwencji wydarzeń, intelektualnie rozwiniętego ducha przedsiębiorczości, angażowania się i służenia innym osobom oraz społeczności ${ }^{16}$. Uzupełnijmy ten zestaw cech liberalnie wykształconej osoby jeszcze o uwagi i postulaty Marthy Nussbaum, od lat broniącej miejsca i znaczenia humanistyki w obszarze edukacji wyższej.

Polemika Nussbaum z Bloomowską koncepcją liberal education zdaje się też oznaczać przesuwanie w niej akcentu z czytania wielkich ksiąg (w poniższym opracowaniu mieszczą się one w ramach edukacji z pierwszej ręki) na poznanie i rozważanie dokonań różnych kultur, aby w ten sposób

\footnotetext{
15 Zob. V. Ferrall Jr., dz. cyt., s. 17.

16 Tamże, s. 18.
} 
przejawianą w edukacji troską o człowieczeństwo kształtować ludzi wolnych - obywateli świata. Również tu wyodrębnia się istotne cechy liberalnie edukowanych osób, a mianowicie zdolność: „do krytycznego badania samego siebie oraz swojej tradycji”, „uznawania siebie nie tylko jako obywateli jakiegoś lokalnego regionu czy grupy, ale także, a zarazem przede wszystkim, za istoty ludzkie związane $\mathrm{z}$ innymi istotami za pośrednictwem więzi wzajemnego uznania i szacunku” oraz „,narracyjnej wyobraźni”, czyli „stawiania się w sytuacji osoby od nas odmiennej, bycie wnikliwym czytelnikiem jej historii, rozumienie jej emocji, życzeń i pragnień"17. Jest to ciekawa propozycja, również warta upowszechniania, w tym odnajdywania i realizowania na niższych szczeblach edukacji, ze względu na formułowanie w niej nowych ważnych celów edukacji liberalnej. Myślę, że także ona mieści się w ramach proponowanej tu idei edukacji z pierwszej ręki; jej zakres tylko znacznie się poszerzył (wychodzi poza obręb wielkich klasycznych ksiąg), ale - jak zostało to zasugerowane wcześniej - również szkolna aktywność uczniów, której wynikiem są samodzielnie projektowane dzieła różnego rodzaju, także może być jej odmianą.

Wymienione przed chwilą cele edukacji liberalnej - oglądane pod kątem ich realizacji na poziomie szkół wyższych, w tym w wyodrębnionych kolegiach Liberal Arts - chciałoby się jednak traktować jako cele edukacji w ogóle. Ale w takim razie nie traćmy z oczu wyróżników tej edukacji i starajmy się uwzględniać je - choć w różnym stopniu i postaci - także we wcześniejszych etapach kształcenia. W przeciwnym razie edukacja wolnych, wrażliwych, samodzielnie i krytycznie myślących ludzi znów zamykałaby się w wąskim kręgu elit. Edukacja liberalna mająca na uwadze cele wskazane wyżej przez Ferralla i Nussbaum ma szanse rozciągać się w czasie, obejmując swym zasięgiem nie tylko szkolnictwo wyższe ale także średnie, a nawet etap powszechnej obowiązkowej edukacji dla wszystkich (pomimo wikłania się liberalności w konflikt z przymusem szkolnym).

\section{Kształcenie ogólne w polskiej edukacji}

Odłóżmy jednak na chwilę rozważania wokół edukacji liberalnej, by zrobić miejsce dla myśli, która mocniej odzwierciedla ducha edukacyjnego naszego polskiego społeczeństwa. Jakim potencjałem dysponuje jej odpowiednik, mający już długą historię i dobrze u nas zadomowiony, czyli koncepcja

\footnotetext{
${ }^{17}$ M. Nussbaum, $W$ trosce, s. $18-19$.
} 
kształcenia ogólnego? Na grunt polski mistrzowsko przenieśli ją i rozwinęli Sergiusz Hessen oraz Bogdan Nawroczyński, obaj twórczo przywołując między innymi Humboldtowską koncepcję Bildung. Była to jednak recepcja rozwijana krótko, bo w okresie międzywojnia, później mocno przygłuszona i zamieniona na idee szkoły ogólnokształcącej w rzeczywistości PRL-u. Zarówno w wykładni Hessena, jak i Nawroczyńskiego zwraca uwagę wielkie zrozumienie dla niemieckiego nurtu neohumanizmu w pedagogice i dla pojęcia (wy)kształcenia rozwijanego w jego obrębie przez Wilhelma von Humboldta, a później przez takich przedstawicieli hermeneutyki filozoficznej, jak między innymi H.-G. Gadamer, F. Schleiermacher czy W. Dilthey. Nie brak w tej myśli również wpływów innych myślicieli, choćby G. Kerschensteinera i J. Deweya. I choć w wydaniu Humboldta kształcenie miało wydźwięk zdecydowanie liberalny, czego oznaką było wyróżnianie w nim wysiłku samej osoby podejmującej starania o kształcenie siebie i zaznaczającej w ten sposób swoją indywidualność ${ }^{18}$, to jednak po przeniesieniu tej idei na grunt polski i zastosowaniu w praktyce szkolnej ten element „wykształcenia liberalnego" w dużej mierze nie zaistniał. Zwyciężyła opcja obowiązkowego kanonu wiedzy, w którą liceum ogólnokształcące miało wyposażyć na znak szacunku i uznania dla dziedzictwa kultury, w kontakcie z którą jednostka ma szansę kształtować swoją osobowość. „Kształcenie się” zostało więc ze szkoły średniej wyprowadzone, w jego miejsce zagościło „kształcenie”. A szkoda, bo Hessenowska wykładnia zawierała w sobie i dokładnie opisywała tę liberalną stronę edukacji: prawdziwe kształcenie - jak pisał Hessen - „,nie przygotowuje, czyli urabia, ani wytwórcy dóbr gospodarczych, ani poddanego państwa, ani nawet syna Kościoła, dbającego o pośmiertny los swojej duszy, lecz kształci człowieka jako takiego, człowieka jako autonomiczną osobowość. Dlatego też kształcenie nie może być narzucone z zewnątrz i z góry jako pewna suma gotowych wiadomości lub przepisów moralnych; ono może i powinno być dziełem samego człowieka. Jest ono sprawą samego kształcącego się człowieka, jego sumienia, rozumu i własnego wysiłku woli"'19.

Ogólnokształcące liceum było w stanie realizować głównie dwie z trzech stron wykształcenia. Rozwój osobowości miał się dokonywać w kontakcie ze światem historycznym i kultura, poprzez przyjęcie praw i nakazów po-

18 Zaznacza to wyraźnie B. Nawroczyński w rozprawie poświęconej koncepcji Bildung Humboldta, zob. Człowiek $i$ wykształcenie w filozofii Wilhelma Humboldta, „Przegląd Współczesny" LV (1935), s. 369.

19 S. Hessen, O sprzecznościach i jedności wychowania, Warszawa 1997, s. 121. 
nadjednostkowych regulujących życie społeczne oraz włączenie do świata dóbr kultury, w których przejawia się ludzka duchowość. Mówiąc słowami Hessena, wykształcenie miało być: „wdrożeniem osobowości człowieka do tradycji kulturalnej, tj. do twórczego potoku życia duchowego, w którym człowiek ma wziąć czynny udział” oraz rozumieniem „materialnych zabytków twórczości duchowej” jako niezbędnego warunku „wdrożenia do tradycji" ${ }^{20}$. Łatwo skonstatować efekt takiego okrojonego pojęcia wykształcenia z pominięciem - jako równorzędnego - czynnika subiektywnego, związanego z indywidualnym wysiłkiem woli jednostki chcącej się kształcić w ten sposób, wiedzionej ciekawością poznawczą, chęcią zgłębiania wiedzy, rozumienia praw przyrody, poznawania prawideł życia społecznego, twórczego odbioru dzieł humanistyki opisującej świat ludzkich wartości. W tej sytuacji pozostaje encyklopedyzm, oczytanie, erudycja, być może ogłada jednak nie w wydaniu akademickim, niepokornym, krytycznym, pytającym, ale w szkolnym uładzonym, z wpisanym weń konformizmem, przystosowaniem, znajomością kanonicznej interpretacji klasycznych dzieł, zjawisk kultury i wydarzeń historycznych, a w dzisiejszej testowej rzeczywistości byleby utrafić w klucz pozwalający uzyskać maksimum punktów, zdobyć certyfikat, dyplom i przejść przez kolejny szczebel drabiny edukacyjnej na drodze awansu i kariery. Zdecydowanie nie ma tu śladu liberal education, choć taki był pierwotny zamysł reformatorów pedagogicznych, chcących tradycję sztuk wyzwolonych ożywić i upowszechnić dzięki nowej ogólnokształcącej formule szkół średnich ${ }^{21}$. Kończący ten etap edukacji akord w postaci matury, mający być symbolem osiągniętej dojrzałości umysłowej, zdobycia wykształcenia jako progu samodzielności i niezależności osoby, dziś stracił dużo ze swego pierwotnego znaczenia, pozostając świadectwem dojrzałości już tylko z nazwy.

\section{Kształcenie ogólne a liberal education - w poszukiwaniu równowagi}

Przy całej krytyce dzisiejszego kształtu edukacji licealnej nie można pomijać mocnych stron i zalet samej koncepcji leżącej u jej podłoża - kształcenia ogólnego. Jego szczytny cel - wszechstronne i wyposażające w wysokie kompetencje umysłowe kształcenie młodych ludzi jest godny podtrzymywania jako ambitny również dziś. $Z$ tego samego powodu powinien i jest roz-

\footnotetext{
20 Tamże, s. 152.

${ }^{21}$ Por. tamże, s. 141.
} 
szerzany na wcześniejsze i równolegle rozwijane szczeble kształcenia. Takie propozycje formułował już wiek temu przedstawiciel pedagogiki kultury Georg Kerschensteiner, postulując rozszerzenie programu szkół zawodowych o przedmioty z zakresu wiedzy ogólnej, nie pozwalające im zesztywnieć $\mathrm{w}$ formule czysto utylitarnego przyuczania do wykonywania zawodu. Równie postępowe pomysły w podobnym czasie głosił i realizował za oceanem filozof i pedagog John Dewey, wnosząc do szkół wiew pragmatyzmu i przewietrzając programy szkolne przesiąknięte formalizmem inicjatywą uczniowską pracy projektowej na rzecz stosowania wiedzy w praktyce życia. Zasługi Deweya na polu reformy edukacji są tej miary, że znajdują swoje odbicie i w myśli orędowników kształcenia ogólnego, i wśród zwolenników liberal education. Dzisiejsze nawiązywanie do Deweyowskich klasycznych już rozwiązań demokratyzacji i unowocześniania szkoły przez Bruce'a Kimballa $^{22}$, znawcy i propagatora edukacji liberalnej, świadczy o tym, że koncepcja ta - choć stara się o nagłaśnianie znaczenia humanistyki w obszarze nauki i edukacji - nie musi być uosobieniem postaw konserwatyzmu i tradycjonalizmu $^{23}$. Podobnie do kształcenia ogólnego, edukacja liberalna nie chce tracić z pola widzenia wielkich osiagnięć ludzkości przechowywanych, rozwijanych i udostępnianych w procesie kształcenia ${ }^{24}$, ale chce to robić odwołując się do twórczej swobodnej energii zaangażowanych, zaciekawionych młodych ludzi, przygotowywanych nie do niszczenia zastanego świata i nie do jego konserwowania, ale do jego odnawiania ${ }^{25}$.

Warto w tym miejscu przywołać jeszcze raz Sergiusza Hessena jako wielkiego orędownika idei wykształcenia ogólnego. Jego myśl pozostaje aktualna do dziś i w niejednym miejscu inspiruje również autorkę poniższego opracowania. O ile tradycyjny podział na szkolnictwo ludowe i średnie, dzielący obszar edukacji na ten dla ludu pracującego i dla inteligencji, być może mamy już za sobą, to - jak pisze Hessen - było to możliwe dzięki idei kształcenia ogólnego właśnie, jako tej, która miała za cel jednoczyć i budować ciagłość między różnymi postaciami i szczeblami kształcenia, zasypując podziały i nierówności społeczne, która miała przygotowywać i „do wczasów" i do pracy ${ }^{26}$.

${ }_{22}$ Zob. B. Kimball, Toward Pragmatic, s. 1-122.

${ }^{23}$ Takie oceny przypisuje się niektórym obrońcom liberal education. Zob. M. Nussbaum, W trosce, s. 317-318.

${ }^{24}$ Por. J. S. Mill, dz. cyt., s. 133.

25 Zob. M. Łuczewski, Edukacja liberalna, „Mishellanea” 1 (2009), s. 78-79.

${ }^{26}$ Zob. S. Hessen, dz. cyt., s. 141. 
Mając na uwadze jednoczący sens i szeroki zakres oddziaływania kształcenia ogólnego w Polsce, obejmujący już bez mała cały obszar edukacji, w myśl Hessenowskich słów, że „każde prawdziwe kształcenie jest wykształceniem ogólnym", wydaje się bardzo rozsądnym rozwiązaniem - na rodzimym gruncie - spróbować wnieść do tej wartościowej samej w sobie koncepcji ten brakujący element, tak uwierający w jej praktycznym polskim wydaniu. Chodzi o liberalność edukacji, czyli wzbudzenie woli samokształcenia, aktywności osobistej uczącego się, bo - parafrazując słowa Hessena każda prawdziwa edukacja jest edukacją liberalną. „Generując autonomię indywiduum" ${ }^{27}$ jest „samostanowieniem osobowości” ${ }^{28}$, jest samoedukacja, aktem wolnego podmiotu. Jeśli koncepcji kształcenia ogólnego udało się wyjść poza początkowe zorientowanie na reformę szkolnictwa średniego i z czasem objąć swym zasięgiem także niższe szczeble edukacji, to analogiczne rozszerzenie powinno móc objąć także edukację liberalną. Jednak w polskiej rzeczywistości edukacyjnej, o ile dostrzegamy tendencję rozszerzania się zasięgu kształcenia ogólnego nie tylko w dół, lecz także w górę, włącznie z poziomem akademickim (pomijając $\mathrm{w}$ tym miejscu przeciwną do niej i również zachodzącą odwrotną tendencję zwrotu w kierunku uzawodowienia szkolnictwa wyższego, nie wyłączając uniwersytetów), to dla zachowania równowagi między obiema tradycjami tym bardziej zasadne jest kierowanie edukacji liberalnej w dół szczebli kształcenia i znajdowanie dla niej gruntu w różnych przestrzeniach edukacyjnych, a nie tylko w obszarze akademickim.

\section{Edukacja liberalna a obowiązek szkolny i obligatoryjność humanistyki}

Ale w takim razie stajemy wobec trudnej kwestii godzenia wolności z przymusem i obowiązkiem. Czy jest to konflikt do rozwiązania i w jaki sposób? O ile ogólność dało się bez trudu wprząc - w imię obrony kanonu wiedzy - w obowiązkowy cykl kształcenia, o tyle liberalność w warunkach przymusu zdaje się tracić całą swoją energię. W tym miejscu warto powrócić do rozważań Marthy Nussbaum, która celnie trafiła w czuły punkt tej zanurzonej w dziejach koncepcji. Wskazała mianowicie dwie drogi, którymi

${ }^{27}$ R. Kosselleck, O antropologicznej i semantycznej strukturze edukacji, w: tenże, Semantyka historyczna, Poznań 2012, s. 446.

28 Tamże, s. 425. 
może iść edukacja liberalna; jedną z nich nazwała arystokratyczna, drugądemokratyczną ${ }^{29}$. Sama autorka - odnosząc się do edukacji wyższej - opowiada się zdecydowanie za drugą, wychodząc z założenia o wadze humanistyki w kształceniu studentów. Ceną tej drugiej jest to, że choć młodzi ludzie podejmują studia z własnego wyboru, wolni od przymusu nauki, to proponuje się, by w ich ramach miały miejsce obligatoryjne dla wszystkich studentów - w imię troski o człowieczeństwo oraz krzewienia idei światowego obywatelstwa - kursy z zakresu humanistyki, dzięki czemu stara koncepcja kształcenia - dla ludzi wolnych - może przyjąć postać nowej demokratycznej akademii ksztattujacej ludzi wolnych [podkr. moje - KW] ${ }^{30}$. Możemy więc konstatować, że na ołtarzu demokratycznych ideałów w powiązaniu z oświeceniowym uniwersalnym przesłaniem kultywowania człowieczeństwa liberalna edukacja zaczyna upodabniać się do ogólnej. Nie musi to jednak oznaczać przegranej tej pierwszej, wszak liberalność może objawić się w całej krasie w sposobie realizacji takich obligatoryjnych kursów. Samo podkreślanie ich wagi staje się bowiem dziś wręcz obowiązkiem nie tylko w imię demokracji, ale jeszcze bardziej wobec tendencji wypłukiwania z programu studiów kursów niezwiązanych bezpośrednio ze specjalnością i przyszłą profesją.

W odniesieniu do edukacji na niższych szczeblach szczytne demokratyczne ideały jeszcze wyraźniej zaznaczyły swój ślad. Zdołały bowiem rozwiązać - przynajmniej w Europie - problem dostępności wiedzy dla dzieci, gwarantując im prawo do nauki, z wydatnym udziałem w tym państwa. Zabezpieczeniem tego uprawnienia był wprowadzany w ciagu XIX wieku obowiązek szkolny, wydłużany z każdą dekadą o kolejne lata, mający za sobą głosy najbardziej światłych i liberalnych umysłów. Wraz ze stopniowym wydłużaniem obowiązkowej nauki aż do poziomu edukacji ponadpodstawowej problem obecności w niej wiedzy spełniającej kryteria edukacji liberalnej stawał się coraz bardziej konkretny. Jednak czy państwo jest skłonne finansować ten model kształcenia uczący samodzielnie, krytycznie myśleć, a nie tylko opanować quantum wiedzy przydatnej do wykonywania zawodu? Edukacja jest dziś sprawą podlegającą prawu umowy społecznej, bo w grę wchodzi wybór i zgoda większości społeczeństwa na model, względnie modele,

${ }_{29}$ Zob. M. Nussbaum, $W$ trosce, s. 314-315.

30 Zob. tamże, s. 313 oraz tenże, Liberal Education \& Global Community, "Liberal Education" Winter 2004 http://www.aacu.org/liberaleducation/le-wi04/le-wi04feature4.cfm (data dostępu: 24.11.2013). 
kształcenia, objęte składką publiczną. Idąc więc dalej, czy jest zgoda i wola społeczna, by finansować publiczną edukację liberalną? Na jakim szczeblu?

Dobrowolność - historycznie najstarsza cecha liberal education - przegrywa dziś z równością, powszechnością, dostępnością - postulatami oświatowymi głoszonymi w imię realizacji ideałów demokracji. Nie ujmując nic egalitarnym celom, wydaje się istotnym punktem w całej sprawie nie tracić z pola widzenia odrębności obu celów. Zdając sobie sprawę z trudności godzenia równości z dobrowolnością, o ile traktujemy je jako równie ważne, możemy próbować szukać między nimi równowagi, zachowując świadomość tego, co tracimy, gdy jeden z nich zaczyna wyrastać nad drugi. Isaiah Berlin tę sytuację nazywał konfliktem niewspółmiernych wartości i był, jako reprezentant agonistycznego liberalizmu, rzecznikiem nazywania rzeczy po imieniu w kategoriach zysków i strat. Prezentowane w niniejszym opracowaniu stanowisko broni nazywania liberalną tej edukacji, w której są obecne wszystkie trzy jej wyróżniki łącznie ze sposobem jej realizacji w postaci edukacji z pierwszej ręki. Jeśli więc argumentujemy za wariantem powszechnej obowiązkowej wszechstronnej edukacji, z pewnością spełnia ona kryteria ogólnej, ale nie nazywajmy jej od razu liberalną. Trzeba by w niej odszukać i zabezpieczyć choć domieszkę dobrowolności i gotowości samokształcenia po stronie uczącego się w kontakcie z żywą nieprzetworzoną myślą czy $\mathrm{w}$ autorskim działaniu. Broniąc z kolei liberalnej, w imię zasady wolności, która ją funduje, możemy ją zobaczyć w świetle indywidualności, zróżnicowania i nieskrępowania przymusem, jednak za cenę niepowszechności ${ }^{31}$. Wszak nie można do niej zmusić. Obie siebie potrzebują i wzajemnie uzupełniają; pierwsza, z jej obroną kanonu wiedzy i mocą zobowiązująca, jest podstawą dla drugiej z jej rangą i mocą zasługującą.

\section{Zakończenie}

Na koniec nie sposób nie wyrazić choć garści sugestii i wyobrażeń na temat możliwości urzeczywistniania w Polsce liberal education. W myśl przyjmowanego tu założenia o szerszym, a nie tylko akademickim rozumieniu edukacji liberalnej sensownym rozwiązaniem byłoby - obok propozycji dotyczącej studiów wyższych - implementowanie jej do niższych szczebli kształcenia na zasadzie uzupełniania kształcenia ogólnego o jego liberalne składniki.

31 Zob. L. Strauss, Sokratejskie pytania, Warszawa 1998, s. 276. 
Odnośnie do poziomu akademickiego, o ile miałaby się ona u nas rozwijać na podstawie amerykańskich pomysłów dotyczących kolegiów artes liberales, pozostałaby niszowa i elitarna w znaczeniu, który krytykują jej pomysłodawcy i zwolennicy (skrzydło egalitarne liberalnych filozofów edukacji), dostępna dla nielicznych. Większą szansę ma utrzymywanie w obrębie studiów wyższych humanistycznych kursów realizujących cele edukacji liberalnej, obok specjalistycznej, choć w części wybieranych przez samych studentów, a nie tylko obligatoryjnych. Równie rozsądnym posunięciem byłoby uznanie studiów licencjackich z filozofii za przygotowanie do studiów magisterskich. Ale wtedy wymagałoby to zgody na studiowanie formalnie dwóch kierunków (w znaczeniu nieobciążenia odpłatnością za drugi): jednym z nich byłaby filozofia na poziomie licencjatu jako forma edukacji liberalnej, drugim - studia specjalistyczne w wybranej dziedzinie wiedzy na poziomie magisterskim.

Odnośnie do poziomu poniżej akademickiego, to ogólnokształcąca formuła nie dość wyraźnie upomina się o tak potrzebne w Polsce i upowszechniane za sprawą edukacji swobodne, krytyczne, samodzielne myślenie młodych ludzi, kojarząc się bardziej z zabezpieczaniem przekazu kanonu wiedzy, dziś w dodatku sprawdzanego dzięki mierzalnym, obserwowalnym, dające się zastosować $\mathrm{w}$ praktyce efekty kształcenia. W obecnym systemie publicznej edukacji więcej ofert w tym zakresie proponują instytucje kształcenia nieformalnego i jest to warte nie tylko podkreślenia, lecz także wykorzystanie również przez szkoły, które mogłyby podjąć szerzej zakrojoną współpracę z tymi placówkami. Same szkoły zyskałyby z kolei przez większą adaptację pomysłów Deweyowskiej pedagogiki pragmatyzmu, w tym przez upowszechnienie indywidualnej i grupowej pracy projektowej uczniów. Dużym polem do uruchamiania uczniowskiej aktywności, poza obowiązkową nauką, jest też działalność samorządowa na terenie szkoły oraz twórczość i zaangażowanie $w$ wybieranych przez uczniów, odpowiadających ich zainteresowaniom, kółkach, sekcjach sportowych, artystycznych oraz w innych formach rozwijającej aktywności, bazujących na dobrowolności. Młody człowiek mający dostęp do wiedzy i mogący ćwiczyć swoje uzdolnienia pisał Mill - „znajduje niewyczerpane źródło zainteresowań we wszystkim, co go otacza; w przyrodzie, dziełach sztuki, tworach poetyckiej wyobraźni, wydarzeniach historycznych, w badaniu dróg, którymi ludzkość kroczyła i kroczy, i jej perspektyw na przyszłość"32. Czy ma szansę korzystać z zasobów kultury umysłowej w toku formalnej edukacji szkolnej i uniwersytec-

32 J. S. Mill, Utylitaryzm, w: tenże, Utylitaryzm. O wolności, Warszawa 2005, s. 19. 
kiej? Czas pokaże, czy właściwą dlań nazwą okaże się proponowana tutaj „edukacja liberalna”. Może ostatecznie przyjmie się inna, byleby zachować w przestrzeni edukacji jej związek z ludzką wolnością i jej humanistycznym obliczem.

\section{Liberal Education in Poland: between Liberal and General Education (Summary)}

The text considers the issue of liberal education and its possibilities to develop in Poland. It has adopted a broader interpretation of understanding the education, as not limited to the academic education but also having its place at lower degrees. It has been postulated that its distinguishing features should be more present in education as such. The features are as follows: the availability of the first-hand knowledge, its critical in-depth understanding including a broad cognitive perspective immanent to the various forms of knowledge, and making a voluntary mental effort based on the learner's need of self-education and the growth of intellectual culture. The text also considers the problem of how the well-established general education in Poland may interact with liberal education and to what extent it may compete with liberal education and impede its implementation.

Keywords: liberal education; general education; self-education; voluntariness; intellectual culture.

\section{Liberal education w Polsce. Między kształceniem ogólnym a edukacją liberalną (Streszczenie)}

Tekst rozważa problem liberal education jako edukacji liberalnej i jej możliwości rozwijania w Polsce. Przyjmuje się w nim szerszą wykładnię jej rozumienia, które nie ogranicza jej do poziomu kształcenia akademickiego, ale szuka dla niej miejsca także na niższych stopniach kształcenia. Postuluje się, by to, co ją wyróżnia, mogło wyraźniej stać się częścią edukacji jako takiej. A są to: dostępność wiedzy $\mathrm{z}$ różnych dziedzin, jej krytyczne pogłębione rozumienie z szeroką perspektywą poznawczą właściwą dla różnych form wiedzy oraz podejmowanie przez uczącego się dobrowolnego wysiłku umysłowego przez potrzebę samokształcenia i wzrost kultury umysłowej. Pojawia się pytanie, na ile ugruntowane w Polsce kształcenie ogólne może współgrać z edukacją liberalną, a na ile konkurować i utrudniać jej realizację.

Slowa kluczowe: edukacja liberalna; kształcenie ogólne; samokształcenie; dobrowolność; kultura umysłowa. 